\title{
PENGARUH KEJELASAN LABELISASI HALAL DAN PERILAKU BERAGAMA \\ TERHADAP MINAT BELI KONSUMEN: ANALISIS DUA MODEL ALTERNATIF
}

\author{
Wahyu Dwi Apriyanto \\ Institut Ilmu Sosial Politik, Jakarta, Indonesia
}

Ignatius Heruwasto

Fakultas Ekonomi dan Bisnis Universitas Indonesia, Depok, Indonesia

Email: heruwasto@yahoo.com

\begin{abstract}
The Influence of Halal Labelization and Religious Behavior of Consumer Buying Interest: Analysis of Two Alternative Models. This research was conducted to determine the effect of clarity on halal labels, and religious attitudes and behavior on consumer buying interest. The attitude and behavior of Muslims in buying a product is influenced by the presence or absence of halal labels and religious attitudes and behavior. But at this time no one has examined the impact of the clarity / clarity of the halal label on a product in influencing the desires of Muslim consumers. In this study two models were developed, in which the first model wanted to see the impact of the clarity of halal labeling together with religious behavior as a purely independent variable effect on buying interest. Whereas alternative models or moderation models, want to see the possibility of halal label clarity as a moderating relationship between religious behavior and buying interest. This study shows that the clarity of the halal label is not a moderating variable on the relationship between religious behavior and buying interest, but it is a purely independent variable that together religious behavior encourages buying interest. The results showed that the clarity of the halal label is a major factor that can encourage buying interest in Muslim consumers. Then furthermore, the level of observance of Muslims in implementing religion/ religious observance also encourages interest in buying halal products.
\end{abstract}

Keywords: Halal Labeling, Religious Behavior, Hablumminallah, Hablumminannas, Halal Products

Abstrak: Pengaruh Kejelasan Labelisasi Halal dan Perilaku Beragama Terhadap Minat Beli Konsumen: Analisis Dua Model Alternatif. Penelitian ini melihat pengaruh kejelasan label halal, dan sikap serta perilaku beragama terhadap minat beli konsumen. Sikap dan perilaku umat muslim dalam membeli suatu produk dipengaruhi oleh ada tidaknya label halal serta sikap dan perilaku beragama. Tetapi saat ini belum ada yang meneliti dampak jelasannya / kejelasan label halal dalam suatu produk dalam mempengaruhi keinginan konsumen muslim. Dalam penelitian ini dikembangkan dua model, dimana model pertama ingin melihat dampak kejelasan labelisasi halal bersama-sama dengan perilaku beragama sebagai variabel independen 
murni pengaruhnya terhadap minat beli. Sedangkan model alternatif atau model moderasi, ingin melihat kemungkinan kejelasan label-halal sebagai moderasi hubungan antara perilaku beragama terhadap minat beli. Penelitian ini menunjukkan bahwa kejelasan label halal bukan merupakan variabel moderasi terhadap hubungan antara perilaku beragama dengan minat beli, tetapi merupakan variable independen murni yang bersama-sama perilaku beragama mendorong minat beli. Hasil penelitian menunjukkan bahwa kejelasan label halal merupakan faktor utama yang dapat mendorong minat beli konsumen muslim. Kemudian selanjutnya, tingkat ketaatan muslim dalam melaksanakan agama/ taat dalam beragama juga mendorong minat beli produk halal.

Kata Kunci: Labelisasi Halal, Perilaku Beragama, Hablumminallah, Hablumminannas, Produk Halal.

\section{INTRODUCTION}

Dinamika sosial politik yang seringkali menyinggung masalah agama, menyebabkan secara tidak langsung berdampak kepada pola pikir dan perilaku masyarakat yang semakin mengenal atau setidaknya terpengaruh oleh nilai-nilai agamanya secara lebih dalam. Hal ini mendorong strategi pemasaran yang menggunakan pendekatan agama, terutama untuk produk makanan, minuman, obatobatan, dan juga fashion. Suatu produk dapat diminati tidak hanya karena faktor utilitarian value atau commercial value, tetapi lebih dari itu juga karena norma dan aturan / cultural meaning (McCracken, 1986).

Dalam buku Majmu 'Fatawa Ibnu Taimiyah, Aidi (2008) dan Wibowo (2010) menjelaskan ibadah mengatur ketentuan Islam dalam bersikap dan berperilaku. Kaidah islam tersebut menyangkut proses interaksi manusia dengan Tuhan, atau perilaku hablumminallah. Sementara itu, Muamalat mengatur pada ketentuan Islam dalam proses interaksi manusia dengan orang lain, atau perilaku hablumminannas.

Ketika seorang Muslim memilih untuk hanya mengkonsumsi produk halal, itu adalah bentuk tingkah laku sebagai seorang Muslim yang terbentuk oleh pengetahuan dan keyakinannya mengenai kebenaran dalam ajaran agama Islam. Ini merupakan bentuk upaya seseorang untuk mematuhi aturan Islam yang berasal dari Al-Quran dan Hadis Nabi Muhammad SAW.

Telah banyak penelitian yang menunjukkan adanya pengaruh Label-halal terhadap minat beli (Wibowo dkk, 2010), Namun belum terlihat adanya penelitian yang melihat kejelasan label halal (label halal yang jelas serta terlihat menarik) 
Wahyu Dwi Aprianto, dkk.: Pengaruh Kejelasan Labelisasi...

dampaknya terhadap minat beli. Juga belum terjelaskan apakah label-halal sebagai variable moderasi terhadap hubungan antara perilaku beragama dengan intensi membeli, atau sebagai variabel independen (Aisyah Muniaty 2014, Fatmasari Sukesti dan Mamdukh Budiman 2014).

Tujuan dari penelitian ini, pertama untuk melihat hubungan pengaruh kejelasan label halal dan perilaku beragama terhadap minat beli. Kedua, untuk menguji dua kemungkinan model hubungan; apakah kejelasan-label-halal sebagai variable anteseden (independen variable) atau sebagai variable moderasi. Selanjutnya, dari kedua faktor tersebut maana yang lebih mempengaruhi intensi membeli seorang muslim.

\section{LANDASAN TEORI}

Agama merupakan faktor terpenting dalam pembentukan budaya, dan akan selalu berkembang secara dinamis dalam masyarakat, dan akan memberikan identitas bagi anggotanya. Islam juga merupakan suatu cara hidup yang ditafsirkan sebagai gaya hidup Muslim yang sesuai dengan syariah (hukum Islam), yang berasal dari Al-Qur'an suci dan Hadis Nabi Muhammad. Lebih lanjut, Aidi (2008) menjelaskan bahwa Islam sebagai cara hidup adalah upaya manusia untuk mencapai kesejahteraan dalam hidupnya di dunia dan akhirat. Allah SWT sudah memberikan pembinaan melalui utusan-Nya yang mencakup semua kebutuhan manusia untuk mendapatkan kesejahteraan mereka sesuai dengan aqidah (iman), akhlak (cara) dan syariah.

Aqidah dan Akhlak bersifat konstan dan tidak berubah dari waktu ke waktu. Sementara itu, Syariah selalu berubah sesuai dengan kebutuhan masyarakat dan peradaban yang sesuai dalam setiap kurun waktu yang berbeda. Syariah dalam ajaran Islam menekankan pada ibadah (menyembah Tuhan) dan Muamalat (interaksi manusia) dengan cara yang baik dan benar dengan memahami etika dan menerapkannya dalam kehidupan sehari-hari untuk menjadi Muslim yang baik dan benar (Antonio, 2006: 39).

Dalam menjalankan Islam yang benar, seorang muslim terikat oleh tata cara hidup yang benar. Salah satunya adalah untuk hanya mengkonsumsi produk yang Halal (Burhanuddin 2011). Untuk memastikan bahwa suatu produk Halal, adalah 
pencantuman Label Halal pada produk dan layanan (Apriyanto, Anton, Nugroho 2003).

Labelisasi halal adalah pencantuman tulisan atau pernyataan halal pada kemasan produk untuk menunjukkan bahwa produk yang dimaksud berstatus sebagai produk halal (Rangkuti, 2010). Label halal sebuah produk dapat dicantumkan pada sebuah kemasan apabila produk tersebut telah mendapatkan sertifikat halal dari Lembaga Pengkajian Pangan, Obat-obatan dan Kosmetika Majelis Ulama Indonesia (LPPOM MUI), yakni lembaga resmi yang menentukan halal atau tidaknya suatu produk.

Seorang yang beragama akan menyesuaikan kebutuhan dan keinginan dengan pedoman agama yang diyakininya. Mereka secara intrinsik berkomitmen untuk perintah agama agar mereka bermakna di masyarakat dan di hadapan Tuhan (Robertson 1998, Diati 2000). Demikian pula, seorang muslim akan selalu tertarik (intention) untuk membeli produk yang halal. Labelisasi halal akan memudahkan kaum Muslim untuk memastikan suatu produk layak untuk dikonsumsi. Labelisasi halal selanjutnya akan mendorong minat beli konsumen (Listyoningrum, Anggit. 2012). Dalam penelitian ini kejelasan dalam label halal akan menjadi fokus penelitian dalam dampaknya mendorong intensi membeli atau minat beli.

Minat beli merupakan suatu yang berhubungan dengan rencana konsumen untuk membeli produk atau jasa tertentu (Ajzen, 1985), serta berapa banyak unit yang produk/jasa yang dibutuhkan pada periode tertentu (Kumala, 2012). Terdapat perbedaan antara pembelian aktual dan minat pembelian. Bila pembelian aktual adalah pembelian yang benar-benar dilakukan oleh konsumen itu sendiri sehingga terjadinya proses pembelian, maka minat pembelian adalah niat untuk melakukan pembelian pada saat proses pembelian dan kesempatan mendatang. Perilaku konsumen dipengaruhi oleh faktor produk dan faktor nilai-nilai yang diyakini (Schiffman dan Kanuk. 2007). Label-halal yang melekat pada suatu produk, serta sikap / perilaku beragama akan membentuk sikap / perilaku konsumen terhadap produk.

\section{RESEARCH FRAMEWORK \& HIPOTESIS}


Wahyu Dwi Aprianto, dkk.: Pengaruh Kejelasan Labelisasi...

Dalam pembelian dan konsumsi suatu produk, konsumen selalu akan mengkaitkan nilai-nilai yang dianut dengan minat dan pilihan produk (Ajzen, 1985). Dalam menentukan produk yang akan dibeli, dan dalam menggunakan produk, konsumen akan mencocokkan suatu produk terhadap dirinya. Apabila ada kemiripan (congruence) antara dirinya dengan produk, maka konsumen akan tertarik dan membeli. Menggunakan prinsip tersebut, maka dapat dipahami bahwa perilaku beragama dan kejelasan label halal akan mempengaruhi minat beli konsumen muslim. 


\section{Label Halal}

Label halal adalah pencantuman tulisan atau pernyataan halal pada kemasan produk untuk menunjukkan bahwa produk yang dimaksud berstatus sebagai produk halal, Burhanuddin (2011) dan Rangkuti (2010). Label merupakan bagian yang tidak terpisahkan dari suatu produk yang menyampaikan informasi mengenai produk dan penjual. Menurut Kotler dan Amstrong (2010) label adalah merek sebagai nama, istilah, tanda, lambang, atau desain, atau kombinasinya, yang dimaksudkan untuk mengidentifikasikan barang atau jasa dari salah satu penjual atau kelompok penjual dan mendiferensiasikan mereka dari para pesaing. Label halal adalah perizinan pemasangan kata "HALAL" pada kemasan produk dari suatu perusahaan oleh BPOM. Izinan pencantuman label halal pada kemasan produk yang dikeluarkan oleh BPOM didasarkan rekomendasi MUI dalam bentuk sertifikat halal MUI. Sertifikat halal MUI dikeluarkan oleh MUI berdasarkan hasil pemeriksaan LP BPOM MUI. Dengan demikian label halal adalah label yang diberikan pada produk yang telah memenuhi kriteria halal menurut agama Islam.

Telah banyak penelitian mengenai label halal, namun demikian kurangnya penelitian mengenai tingkat kejelasan label halal yang ada pada kemasan suatu produk, yang menyangkut kejelasan warna, gambar, dan tata letak untuk dapat terlihat menarik atas produk. Menurut Utami (2013), kejelasan label halal sangat penting bagi umat Muslim dalam mengkonsumsi makanan dan minuman. Kejelasan label halal diukur dengan beberapa hal sebagai berikut :

1. Gambar

2. Tulisan

3. Kombinasi gambar dan tulisan

4. Tata letak label halal pada kemasan

Atribut dalam suatu label, selain menunjukkan jaminan terhadap label tetapi juga karena kombinasi tata letak dan kejelasan antara warna dan tulisan dapat memberikan asosiasi yang positir dan membentuk brand equity selanjutnya mendorong intensi untuk membeli konsumen (Aaker 1991). Atas dasar ini, akan diteliti mengenai kejelasan labelisasi halal yang menyangkut penampilan gambar, tulisan, kombinasi gambar dan tulisam, dan tata letak pencantuman dari label halal dalam kemasan. Penelitian ini berpendapat bahwa, menariknya dan kejelasan label 
Wahyu Dwi Aprianto, dkk.: Pengaruh Kejelasan Labelisasi...

halal akan dapat meningkatkan intensi membeli konsumen selain juga pencantuman label halal pada produk.

\section{Perilaku Beragama}

Perilaku beragama adalah sikap seseorang terhadap agamanya secara umum, tidak hanya terhadap satu aspek, tetapi juga terhadap intensitas dan caranya menjadi orang yang religius (Magil, 1993).

Berdasarkan Magil (1993:20), perilaku beragama adalah tindakan seseorang terhadap agamanya secara umum, tidak hanya terhadap satu aspek, tetapi juga terhadap intensitas dan caranya menjadi orang yang religius. Perilaku keagamaan berasal dari setiap sisi kehidupan manusia dan tidak hanya terjadi ketika ia melakukan kegiatan ritual atau agama, tetapi juga ketika ia melakukan kegiatan lain yang didorong dari keyakinan dan kepercayaan agamanya. Oleh karena itu, perilaku beragama tidak hanya berkaitan dengan kegiatan zahir (terlihat), seperti kegiatan berdoa dan beriteraksi terhadap sesama seperti membantu orang miskin, dan lainlain. Tetapi juga terlait dengan hal yang tidak terlihat seperti, menjaga hati ke pada Allah, dan ke dalaman iman seseorang dalam ajaran, serta sikap berserah diri kepada Tuhan / dzikir (Mansore, 2008:28). Perilaku beragama seseorang terbagi dalam dua kelompok; Hablumminallah, dan Hablumminannas.

\section{Perilaku Hablumminallah}

Pada dasarnya, perilaku hablumminallah adalah perilaku keagamaan Islam yang terbentuk dari perilaku kognisi, afeksi dan konasi dalam aspek iman dan ibadah seorang muslim dalam hubungannya dengan Tuhan, yang jelas tertulis dalam dua landasan Islam, yaitu rukun iman, rukun Islam (Mansoer), 2006, Husaini, 2013). Ada enam rukun iman dalam Islam, yaitu iman kepada Allah, iman kepada malaikat Allah, iman kepada kitab-kitab suci Allah, iman kepada rasul-rasul Allah, iman kepada hari kiamat, dan iman kepada qada dan qadar. Sedangkan, lima rukun Islam adalah shahadah (pengakuan keimanan islami, "tidak ada tuhan selain Allah, dan Muhammad adalah utusan-Nya"), shalat (sholat), puasa, zakat, dan menjalankan/menunaikan ibadah haji bila mampu. Dengan demikian, dalam penelitian ini, perilaku hablumminallah konsumen diukur dari tiga dimensi, yaitu 
pengetahuan, Keyakinan dan penerapan iman (enam rukun Iman) dan ibadah (lima rukun Islam).

Pengetahuan terhadap iman dan ibadah dapat diukur dengan rukun islam, rukun iman dan syahadat. Keyakinan terhadap iman dan ibadah dapat diukur dengan berdoa, berpuasa, berzakat dan berhaji. Penerapan terhadap iman dan ibadah dapat diukur dengan sholat wajib, sholat sunnah dan membaca AlQuran.

\section{Perilaku Hablumminannas}

Pada dasarnya, tujuan pelaksanaan ajaran agama didasarkan pada konsep ilahiah (hubungan antara manusia dengan Tuhannya). Konsep ilahiah ini diterjemahkan ke dalam konsep kenabian dan alam semesta yang terkait dengan hubungan manusia dengan dirinya sendiri, orang lain dan lingkungan alam (Husaini, 2013:19). Salah satu ciri syariah Islam adalah syumulliyah (mencakup setiap hal dalam kehidupan sehari-hari Muslim) yang berlangsung dengan konsep perilaku hablumminannas. Konsep hablumminannas adalah tentang segala sesuatu di dunia dan akhirat yang intinya tentang fakta sifat kehidupan manusia (kepribadian, kebiasaan, peristiwa, dan sebab akibat) yang selalu dikaitkan dengan konsep ilahiah (Hidayat, 2014).

1. Kepribadian Islam kepada diri sendiri dapat diukur dengan kejujuran, kedisiplinan dan ketekunan

2. Kepribadian islam kepada sesama manusia dapat diukur dengan baik hati, berbagi dan bekerjasama

3. Kepribadian Islam kepada alam sekitar dapat diukur dengan melestarikan alam, keperdulian terhadap alam dan menjaga lingkugan.

\section{Minat Beli}

Minat beli adalah keinginan konsumen membeli sebuah merek di dalam kategori produk, yang merupakan salah satu tahapan dalam proses pembelian (Bonyadi, Parisa, and Khosro. 2015). Pengembangan konsep minat beli pada suatu produk, tidak hanya dibatasi hanya pada pembelian produk yang belum pernah dibeli, tetapi lebih luas lagi untuk produk yang pernah dibeli/ intention to repeat purchase. 
Minat beli dan minat beli kembali dipengaruhi oleh berbagai faktor seperti kesediaan dan keinginan terhadap produk dan pengaruh eksternal lainnya. Schiffman dan Kanuk. (2007), menjelaskan bahwa pengaruh internal konsumen, kesadaran akan kebutuhan, pengenalan produk dan evaluasi alternative adalah hal yang dapat menimbulkan minat beli konsumen. Pengaruh eksternal ini terdiri dari faktor social, usaha pemasaran, dan faktor social budaya.

Indikator-indikator minat beli dijelaskan memiliki beberapa komponen, yaitu (Schiffman \& Kanuk 2007):

1. Tertarik untuk mencari informasi tentang produk.

2. Mempertimbangkan untuk membeli dan membeli kembali.

3. Tertarik untuk mencoba.

4. Ingin mengetahui produk.

5. Ingin memiliki produk.

\section{HIPOTESIS \& MODEL PENELITIAN}

Hipotesis adalah hubungan yang diperkirakan secara teori dan bersifat logis. Hipotesis merupakan pernyataan mengenai dua atau lebih konsep / variabel yang dapat diuji. Dengan menguji hipotesis akan diketahui bentuk hubungan yang sesuanggunya yang terdapat di lapangan, selanjutnya solusi dapat ditemukan untuk mengatasi masalah yang dihadapi (Sekaran, 2011).

Selain menguji hipotesis penelitian yang menyangkut dampak dari perilaku beragama serta kejelasan label halal, terhadap minat beli. Penelitian ini juga menguji dua model alternative; model dengan independen murni (model pertama), dan model dengan moderasi (model kedua).

\section{Model Pertama}

Model pertama menjelaskan hubungan, labelisasi halal, hablumminallah dan hablummnannas terhadap minat beli. Dimana variable labelisasi halal merupakan variable independen murni yang bukan sebagai variable moderasi.

Melalui rangkuman landasan teori yang telah dibahas pada bagian tulisan sebelumnya, maka dikembangkan hipotesis berikut. Dengan seiring meningkatnya 
Islamiconomic: Jurnal Ekonomi Islam Vol.10 No.2 Juli - Desember 2019

$\overline{\text { sikap dan perilaku hablumminalah dan habluminanas seseorang maka semakin tinggi }}$ minat beli mereka terhadap produk halal. Demikian pula semakin jelas labelisasi halal terlihat oleh konsumen muslim, maka semakin meningkat keinginan beli mereka terhadap produk tersebut. Selanjutnya dapat dikembangkan H1, H2, H3 sebagai berikut. 
H1: Perilaku hablumminallah ber-pengaruh positif terhadap minat beli

H2: Perilaku hablumminanas ber-pengaruh positif terhadap minat beli.

H3: Kejelasan labelisasi halal berpengaruh positif dan signifikan terhadap minat beli.

Tiga hipotesis diatas merupakan model pertama (M1), dimana perilaku beragama dan labelisasi halal merupakan variable independen murni terhadap minat beli pada produk halal. Selanjutnya di bawah ini adalah model penelitian dari M1.

Gambar 1: Model 1

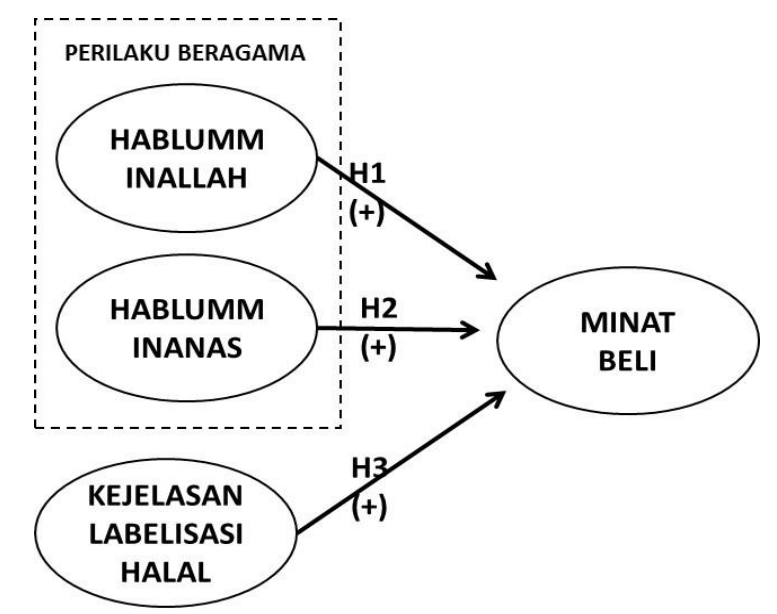

Persamaan Regresi M1 adalah sebagai berikut:

$\mathrm{Y}=\mathrm{a}+\mathrm{b} 1 . \mathrm{HA}+\mathrm{b} 2 . \mathrm{HN}+\mathrm{B} 3 . \mathrm{LH}-->(1)$

\section{Model Kedua (M2)}

Pada penelitian ini, peneliti juga mengembangkan model kedua (M2), yang merupakan model alternatif dari model pertama. Model ini menempatkan kejelasan labelisasi halal merupakan variable yang memoderasi hubungan antara sikap dan perilaku beragama (habluminallah dan habluminanas) terhadap minat beli.

Pada M2, hipotesis 1 (H1) dan hipotesis 2 (H2) mirip dengan yang ada pada model 1 (M1). Berbeda M2 dengan model 1, pada model 2 menempatkan labelisasi halal sebagai variable moderasi sehingga ada tambahan hipotesis moderasi yaitu $\mathrm{H} 4$ dan H5.. 
Model kedua, M2, kejelasan labelisasi halal memoderasi hubungan antara hablumminallah dan hablumminannas terhadap minat beli.

$\mathrm{H}_{4}$ : Labelisasi Halal memoderasi hubungan antara hablumminallah terhadap minat beli.

H5: Labelisasi Halal memoderasi hubungan antara hablumminannas terhadap minat beli.

Gambar 2: Model 2

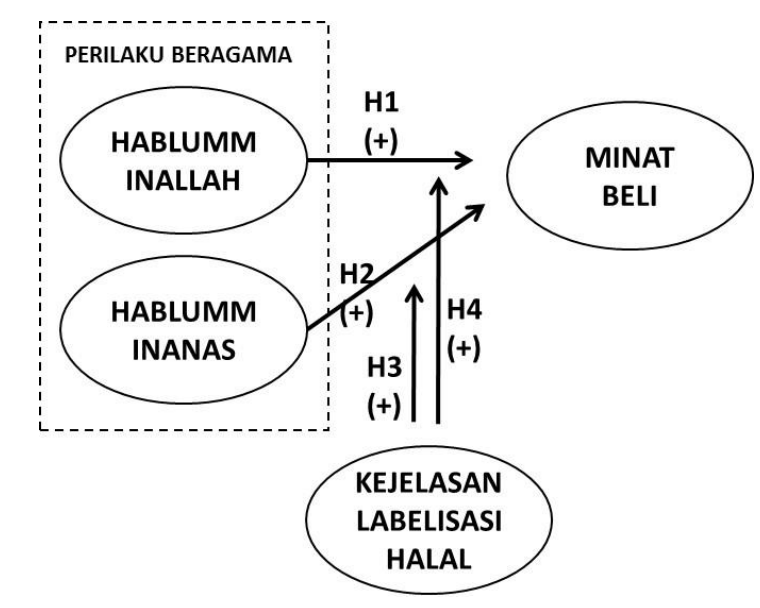

Persamaan Regresi M2 adalah sebagai berikut:

\section{$\mathrm{Y}=\mathrm{a}+\mathrm{b} 1 . \mathrm{HA}+\mathrm{b} 2 . \mathrm{HN}+\mathrm{b} 3 . \mathrm{LH}$ \\ b4.HA*LH+b5.HN*LH -->(2)}

Persamaan regresi diatas merupakan model moderasi dengan menambahkan dua faktor interaksi yaitu HA*LH dan HN*LH. Apabila kedua faktor tersebut dalam pengujian statistik signifikan dengan tanda positif, maka sikap dan perilaku beragama seseorang memiliki efek gabungan bersama kejelasan labelisasi halal, dalam meningkatkan minat beli seorang Muslim terhadap produk halal. Atau dalam bahasa sederhana, terjadi sinergi antara sikap/perilaku beragama dengan kejelasan labelisasi halal dalam mendorong minat beli.

\section{METODE PENELITIAN}

Jenis yang digunakan dalam penelitian ini adalah deskriptif dengan pendekatan kuantitatif. Pada penelitian ini akan dilihat hubungan sebab-akibat antar variabel.

Unit analisis penelitian ini adalah konsumen individu yang menggunakan produk freshcare, produk tissue basah pembersih kulit wajah. Pemilihan jenis produk 
Wahyu Dwi Aprianto, dkk.: Pengaruh Kejelasan Labelisasi...

ini adalah karena banyak digunakan oleh konsumen, dan juga memiliki isu bahan halal yang terkandung di dalamnya yang sering merisaukan umat Muslim.

Data penelitian dikumpulkan dari penumpang KRL jabodetabek yang menggunakan produk pembersih wajah Fresh Care, konsumen yang beragama Islam, sebanyak 100 orang. Dengan jumlah tersebut maka telah terpenuhi kriteria jumlah sampel lebih dari 30, dan telah memenuhi syarat minimal 5 sampel untuk setiap jumlah independent variabel (untuk M1=3x5=15, dan untuk M2=5x5=25).

Teknik penarikan sampel dalam penelitian ini adalah dengan teknik Accidental sampling, yaitu walaupun diusahakan secara acak namun pengambilan sampel lebih didasarkan oleh kemudahaan untuk ditemui. Metode ini biasa digunakan dalam penelitian dengan jumlah sampel yang besar.

Butir pertanyaan untuk mengukur setiap konsep diambil dari konsep teori dan penelitian terdahulu, dengan beberapa modifikasi agar sesuai dengan konteks produk yang dipakai. Dengan demikian penelitian ini telah memenuhi syarat validitas secara teori dan validitas realita.

Tahap pertama penelitian dilakukan pretest untuk memastikan kuesioner telah valid dan reliable. Hasil pretest selanjutnya menghasilkan butir pertanyaan yang layak digunakan pada kuesioner di penelitian utama.

Definisi setiap konsep yang digunakan telah dijelaskan pada bagian sebelumnya tulisan ini. Selanjutnya, operasionalisasi konsep penelitian, adalah sebagai berikut.

- Habluminnallah, memiliki tiga dimensi yaitu; pengetahuan tentang ibadah (PGTH), keyakinan iman dan ibadah (KYKN), penerapan iman dan ibadah (PRPN). Selanjutnya masing-masing dimensi dibuat indicator sebagai berikut: PGTH (rukun iman, rukun islam, syahadat), KYKN (berdoa, puasa, zakat, haji), PRPN (sholat wajib, sholat sunnah, baca Alquran).

- Hablumminannas: memiliki tiga dimensi yaitu; ke diri sendiri (KIKDS), ke orang lain / sesama (KIKSM), kea lam sekitar (KIKAS). Selanjutnya masingmasing dimensi dibuat indicator sebagai berikut: KIKDS (jujur, disiplin, tekun), KIKSM (berbagi, baik hati, bekerjasama/membantu), KIKAS (peduli alam, melestarikan, menjaga). 
- Kejelasan Labelisasi Halal: gambar, tulisan (GMB), kombinasi tulisan dan gambar (TLSN), kombinasi gambar/tulisan/label menarik (KMBS), mencantumkan label halal menarik (MLH).

- Minat Beli: mencari info produk (ITP), mempertimbangkan beli (TP), ingin mencoba (MCB), ingin mengetahui produk MP, ingin mencoba produk (MPR)

Selanjutnya statistic yang digunakan untuk menguji validitas butir pertanyaan adalah factor analisis, dengan ukuran factor loading harus > 0,5 (Sekaran, 2011). Untuk uji reliabilitas butir pertanyaan, digunakan uji coefficient of reliability, dengan ukuran cronbach alpha harus lebih dari 0.6. Untuk uji hipotesis digunakan regresi berganda, dengan kriteria adanya hubungan yang signifikan bila nilai 'Sig' $<0.05$, serta tanda positif atau negatif dari nilai ' $\mathrm{B}$ ' harus sesuai dengan pernyataan arah hubungan hipotesis penelitian (Gozali, 2011).

Untuk uji model, pengolahan regresi akan dilihat kecocokan Model-1 (M1) dibandingkan Model-2 (M2). Setiap model dibuat persamaan regresi berganda (multiple regression) sesuai dengan konsep model masing-masing (persamaan 1, dan persamaan 2).

Model pertama (M1) independen variable merupakan variable yang bersamasama mempengaruhi variable independen (lihat persamaan 1). Dalam persamaan regresi dibawah ini, dengan symbol dari minat beli (Y), Hablumminallah (X1), Hablumminannah (X2), Kejelasan Label Halal (X3).

\section{$Y=a+B 1 . X 1+B 2 . X 2+B 3 \cdot X 3+e \ldots($ persamaan 3$)$}

Model kedua (M2) merupakan model moderasi, sehingga persamaan regresi memasukkan factor interaksi. Berikut adalah persamaan regresi yang akan digunakan dalam analisa regresi.

\section{$Y=a+B 1 . X 1+B 2 . X 2+B 3 . X 3+$}

\section{$B 4 . \underline{X 1 * X 3}+B 5 . \underline{X 2 * X 3}+e \ldots($ persamaan 4$)$}

Selanjutnya untuk melihat model mana yang terbaik, maka hasil regresi dua model tersebut akan dibandingkan pada nilai $\mathrm{R}^{2}$ masing-masing, dimana $\mathrm{R}^{2}$ tertinggi menunjukkan model yang lebih baik dalam menjelaskan variance pada independent variable, atau dapat dikatakan lebih baik (fit) dibandingkan model lainnya. Apabila 
Wahyu Dwi Aprianto, dkk.: Pengaruh Kejelasan Labelisasi...

model dengan interaksi adalah yang lebih baik, syarat berikutnya adalah factor interaksi harus signifikan berpengaruh (nilai sig $<0.05$ ) terhadap minat beli.

\section{HASIL PENELITIAN}

Data yang berhasil dikumpulkan, kemudian diuji butir pertanyaan apakah memenuhi syarat validitas dan reliabilitas. Hasil uji terhadap butir pertanyaan serta dimensinya seluruhnya dinyatakan valid dan reliable, dengan nilai factor score diatas 0.5 dan cronbach alpha diatas 0.6. Hasil pengujian dapat dilihat melalui table 1 dibawah ini, dan selanjutnya dapat digunakan seluruhnya untuk pengujian hipotesis penelitian.

Tabel.1: Validitas \& Reliabilitas

\begin{tabular}{|c|c|c|c|c|c|}
\hline $\begin{array}{l}\text { KONSEP/ } \\
\text { DIMENSI }\end{array}$ & $\begin{array}{l}\text { Loading } \\
\text { Factor }\end{array}$ & $\begin{array}{c}\text { Cronbach } \\
\text { Alpha }\end{array}$ & $\begin{array}{l}\text { KONSEP/ } \\
\text { DIMENSI } \\
\end{array}$ & $\begin{array}{c}\text { Loading } \\
\text { Factor } \\
\end{array}$ & $\begin{array}{c}\text { Cronbach } \\
\text { Alpha }\end{array}$ \\
\hline $\begin{array}{l}\text { Kejelasan } \\
\text { Labelisasi } \\
\text { Halal }\end{array}$ & & & $\begin{array}{l}\text { Hablummi } \\
\text { nannas }\end{array}$ & & \\
\hline - $\quad \mathrm{GMB}$ & & \multirow{5}{*}{0,790} & - $\quad$ KIKDS & 0,680 & \multirow{3}{*}{0,752} \\
\hline - $\quad$ TLSN & 0,824 & & - $\quad$ KIKSM & 0,686 & \\
\hline - $\quad \mathrm{KMBS}$ & 0,751 & & - $\quad$ KIKAS & 0,696 & \\
\hline \multirow[t]{2}{*}{ - $\quad \mathrm{MLH}$} & 0,781 & & Minat Beli & & \\
\hline & 0,776 & & - $\quad$ ITP & 0,787 & \multirow{5}{*}{0,828} \\
\hline $\begin{array}{l}\text { Hablumin } \\
\text { nallah }\end{array}$ & & & - $\quad$ ТP & 0,836 & \\
\hline - $\quad$ PGTH & 0,687 & \multirow{3}{*}{0,778} & MCB & 0,813 & \\
\hline - $\quad \mathrm{KYKN}$ & 0,805 & & - $\quad \mathrm{MP}$ & 0,660 & \\
\hline PRPN & 0,683 & & MPR & 0,839 & \\
\hline
\end{tabular}

\section{Uji Hipotesis Model Pertama (M1)}

Pengujian model pertama dilakukan untuk melihat hubungan antara perilaku beragama (Hablumminallah dan Hablumminannas) dan kejelasan labelisasi halal, terhadap minat beli. Berikut ini adalah hasil table korelasi dan anova hasil dari olahan statistik regresi berganda.

Berdasarkan tabel diatas hasil uji regresi linear berganda Model 1 di dapat tabel summary dari Anova, Korelasi, dan Coefficient.

Tabel.2: Anova M1 
Pengaruh LH/HA/HN ke Minat Beli

\begin{tabular}{|l|c|c|}
\hline & F & Sig. \\
\hline Model 1 & 218.795 & $.000^{\mathrm{b}}$ \\
\hline
\end{tabular}

Sumber: olahan peneliti

a. Dependent Variable: Minat Beli

b. Predictors: (Constant), Hablumminallah, Hablumminannas, LabelisasiHalal

Berdasarkan tabel ANOVA di atas, diperoleh nilai signifikansinya adalah sebesar 0,000, dimana artinya ke tiga variabel independen, yakni labelisasi halal, hablumminallah dan hablumminannas bersama-sama signifikan berpengaruh terhadap variabel dependen, dalam hal ini minat beli. Dikarenakan, nilai dari signifikansinya lebih kecil dari 0,05, dimana merupakan syarat jika signifikansinya lebih kecil dari 0,05, maka terdapat pengaruh signifikan antara variabel independen terhadap variabel dependen.

Tabel.3: Korelasi \& Determinasi M1

HA/HN/LH terhadap Minat Beli

\begin{tabular}{|c|c|c|}
\hline & $\mathbf{R}$ & $\mathbf{R}$ \\
Square \\
\hline $\begin{array}{c}\text { Model } \\
\mathbf{1}\end{array}$ & $934^{\mathrm{a}}$ & .872 \\
\hline
\end{tabular}

Sumber: olahan peneliti

a. Predictors: (Constant), Hablumminallah, Hablumminannas, Labelisasi Halal

Berdasarkan tabel diatas hasil uji regresi linear berganda Model 1 di dapat tabel summary dengan koefisien korelasi (R) sebesar 0,934ª menunjukkan bahwa korelasi antara labelisasi halal, hablumminallah dan hablumminannas dan kejelasan labelisasi halal terhadap minat beli yaitu 93,4\%. Berdasarkan nilai koefisien korelasi tersebut maka tingkat hubungan antar labelisasi halal, hablumminallah dan hablumminannas dan labelisasi halal terhadap minat beli dapat dikatakan sangat kuat. Selanjutnya, nilai R Square, atau koefisien determinasi sebesar 0,872 atau sebesar 87,2\% yang dapat diartikan bahwa ketiga variabel independen dapat menjelaskan variance 
Wahyu Dwi Aprianto, dkk.: Pengaruh Kejelasan Labelisasi...

variabel dependen yaitu minat beli sebesar $87.2 \%$, sedangkan sisanya $12,8 \%$ dipengaruhi oleh variabel independen lain yang tidak diteliti dalam penelitian ini.

Penelitian ini menunjukkan bahwa variable perilaku beragama dan kejelasan dalam labelisasi halal sebagai predictor utama untuk mendorong minat beli suatu produk.

Tabel 4: Koefisien B dari M1:

LH/HA/HN

\begin{tabular}{|l|l|l|}
\hline Model 1 & \multicolumn{1}{c|}{ Beta } & \multicolumn{1}{c|}{ Sig. } \\
\hline$($ Constant $)$ & $-1.00 \mathrm{E}-13$ & 1 \\
\hline $\mathrm{LH}$ & 0.372 & 0.000 \\
\hline $\mathrm{HA}$ & 0.318 & 0.036 \\
\hline $\mathrm{HN}$ & 0.268 & 0.047 \\
\hline
\end{tabular}

Sumber: olahan peneliti

a. Dependent Variable: MinatBeli

Dari data-data yang disajikan pada tabel-tabel diatas didapatkan hasil sebagai berikut:

Tabel diatas, didapatkan nilai signifikan dan beta dari masing-masing variabel independen adalah sebagai berikut:

a. Pengaruh Hablumminallah terhadap minat beli, sig $=0,036$ dan nilai beta $=$ 0,318. Nilai sig < 0,05, ini berarti Hablumminallah memiliki pengaruh signifikan terhadap minat beli. Dengan demikian hipotesis-1, H1 terdukung oleh data. Perilaku habluminallah memiliki pengaruh signifikan terhadap minat beli.

b. Pengaruh perilaku Hablumminannas terhadap minat beli, sig. $=0,047$, dan nilai beta $=0,268$. Nilai sig $<0.05$, ini berarti Hablumminannas memiliki pengaruh signifikan terhadap minat beli. Dengan demikian hipotesis-2, H2 terdukung oleh data.

c. Kejelasan Labelisasi Halal, nilai sig. $=0,000$ dan nilai beta $=0,372$. Nilai sig < 0,05. Dengan demikian hipotesis-3, H3 terdukung oleh data, kejelasan Labelisasi halal memiliki pengaruh signifikan terhadap minat beli.

Melalui table diatas dapat diketahui, variable pengaruh yang terbesar untuk mendorong minat beli berturu-turut adalah; kejelasan labelisasi halal (0.372), habluminallah (0.318), hablumminanas (0.268). 
Tabel 5:

Kesimpulan Uji Hipotesis M1

\begin{tabular}{|l|l|}
\hline \multicolumn{1}{|c|}{ Hipotesis } & Kesimpulan \\
\hline H1: Pengaruh labelisasi terhadap minat beli. & diterima \\
\hline H2: Pengaruh hablumminallah terhadap minat beli. & diterima \\
\hline H3: Pengaruh hablumminannas terhadap minat beli. & diterima \\
\hline
\end{tabular}

Melalui table diatas, selanjutnya, dapat diambil kesimpulan bahwa H1, H2, H3 diterima karena terdukung oleh data.

\section{Uji Hipotesis Model Kedua (M2)}

Pada model ke dua, mirip dengan model pertama tetapi berbeda dengan menambahkan faktor interaksi antara perilaku beragama dengan kejelasan labelisasi halal. Faktor interaksi disertakan dalam model ke dua ini, karena dalam model ini faktor kejelasan labelisasi halal diperlakukan sebagai variabel moderasi.

Dalam model moderasi, pada persamaan regresi ditambahkan dua factor interaksi yaitu HA*LA dan HN*LH, lihat persamaan 2. Dibawah ini adalah hasil tabel anova dengan pengolahan regresi.

Tabel 6: Anova M2

Pengaruh LH,HA,HN,HA*LH, HN*LH, terhadap Minat Beli

\begin{tabular}{|l|c|c|}
\hline & F & Sig. \\
\hline Model 2 & 174.044 & $.000^{\mathrm{b}}$ \\
\hline
\end{tabular}

a. Dependent Variable: MinatBeli

b. Predictors: (Constant), HablumminAllah, HablummiNannas, LabelisasiHalal, HA*LH, HN*LH.

Dari tabel ANOVA di atas, dapat diambil kesimpulan bahwa seluruh antecedent yang ada dalam M2 berhubungan terhadap intensi membeli produk halal. Selanjutnya kekuatan hubungan dan kekuatan penjelasan dapat dilihat melalui tabel di bawah ini.

Tabel.7: 
Wahyu Dwi Aprianto, dkk.: Pengaruh Kejelasan Labelisasi...

Korelasi dan Determinasi M2, HA/HN/LH/LH*HA/HN*LH terhadap Minat Beli

Sumber: olahan peneliti

\begin{tabular}{|c|c|c|c|}
\hline Model & $\mathbf{R}$ & $\mathbf{R}$ & $\begin{array}{c}\text { Ajusted } \\
\text { Square }\end{array}$ \\
Square \\
\hline 1 &, $950^{\mathrm{a}}$ & .902 & .897 \\
\hline
\end{tabular}

1. Predictors: (Constant), LHxHN, LabelisasiHalal, Hablumminannas, HablumminAllah, LHxHA

Berdasarkan tabel diatas, dari hasil pengolahan regresi linear berperoleh koefisien korelasi (R) sebesar 0,950a yang menunjukkan bahwa hubungan antara hablumminallah dan hablumminannas terhadap minat beli yang dimoderasikan oleh labelisasi halal yaitu 95\%, yang artinya adalah kuat. Selanjutnya, nilai R Square $\left(\mathrm{R}^{2}\right)$ sebesar 0,902, yang dapat artinya bahwa variabel independen dengan moderasinya, dapat menjelaskan 90,2\% variance dari variabel dependent (minat beli). Selanjutnya sisanya 8,8\% (100-90.2) dipengaruhi oleh variabel lain diluar variabel penelitian ini.

Terlihat bahwa dari hasil $\mathrm{R}^{2}$, model kedua (M2, $\left.\mathrm{R}^{2}=90.2 \%\right)$ lebih baik dibandingkan model kedua (M1, $\left.\mathrm{R}^{2}=87.2 \%\right)$. Namun peningkatan nilai tersebut tidak besar, hanya meningkat 3\%. Selanjutnya apakah M2 sebagai model yang lebih baik dibandingkan M1, maka harus dilihat nilai signifikan dari kedua faktor interaksi yang ada dalam model dua.

Analisa untuk melihat apakah factor interaksi kejelasan label bersama hablumminallah dan hablumminannah signifikan berpengaruh terhadap minat beli, dapat dilihat melalui tabel di bawah ini.

Tabel 8: Nilai Sig dan Beta

\begin{tabular}{|l|c|c|}
\hline Variabel & Beta & Sig. \\
\hline (Constant) & .033 & .403 \\
\hline LH & .418 & .000 \\
\hline HA & .372 & .000 \\
\hline
\end{tabular}


Islamiconomic: Jurnal Ekonomi Islam Vol.10 No.2 Juli - Desember 2019

\begin{tabular}{|l|c|c|}
\hline $\mathrm{HN}$ & .164 & .050 \\
\hline $\mathrm{LH}^{*} \mathrm{HA}$ & -0.60 & .497 \\
\hline LH*HN & .033 & .799 \\
\hline
\end{tabular}

a. Dependent Variable: MinatBeli

Dari tabel diatas, terlihat nilai signifikan dan beta dari masing-masing variabel dalam Model-2 sebagai berikut:

a. Faktor interaksi antara Labelisasi Halal dengan Hablumminallah, HA*LH, memiliki nilai sig. $=0.497$, kurang dari 0.05. Artinya, factor interaksi, LH*HA tidak signifikan berpengaruh terhadap minat beli. Hal ini menunjukkan bahwa kejelasan labelisasi halal (HL) bukan sebagai moderasi hubungan antara perilaku beragama dengan minat beli. Sebagai kesimpulan, H4 tidak terdukung oleh data.

b. Faktor interaksi antara Label Halal dengan Hablumminannas, HN*LH, memiliki nilai sig. $=.799$, kurang dari 0.05. Artinya, labelisasi halal bukan sebagai moderasi hubungan antara hablumminannas dengan minat beli. Sebagai kesimpulan, $\mathrm{H} 5$ tidak terdukung oleh data.

Tabel 9:

Kesimpulan Uji Hipotesis M2

\begin{tabular}{|c|c|}
\hline Hipotesis & Kesimpulan \\
\hline $\begin{array}{l}\text { H4: Labelisasi halal memoderasi hubungan } \\
\text { hablumminallah terhadap minat beli. }\end{array}$ & ditolak \\
\hline $\begin{array}{l}\text { H5: Labelisasi halal memoderasi hubungan } \\
\text { hablumminallah terhadap minat beli. }\end{array}$ & ditolak \\
\hline
\end{tabular}

Hasil pengujian Model-2 menunjukkan bahwa kejelasan label halal (LH) bukan sebagai variable moderasi pada hubungan perilaku beragama (HA \& HN) dengan minat beli.

\section{KESIMPULAN}

Penelitian ini mengungkapkan bahwa terdapat pengaruh antara kejelasan label halal dan perilaku beragama dalam mendorong minat beli konsumen muslim. Faktor pendorong minat beli yang paling utama adalah kejelasan dari label halal. 
Wahyu Dwi Aprianto, dkk.: Pengaruh Kejelasan Labelisasi...

Selanjutnya, sikap dan perilaku beragama seorang muslim juga mempengaruhi minat beli terhadap produk halal. Faktor yang paling mempengaruhi minat beli produk yang halal adalah sikap terhadap Allah (hablumminallah), dan selanjutnya sikap terhadap sesama manusia (hablumminannah).

Kejelasan labeli halal dan ketaatan dalam beragama seorang muslim akan mempengaruhi minat beli mereka. Implikasi dari hasil penelitian ini, perlu suatu produk untuk mencantumkan label halal letak yang benar, dengan ukuran serta warna yang jelas sehingga menarik dan mudah terlihat oleh konsumen muslim. Untuk selanjutnya perlu adanya penelitian lebih lanjut yang meneliti tentang kejelasan labelisasi halal.

Saat ini, tampaknya para pemasar kurang memberikan perhatian terhadap penampilan logo halal pada produk mereka. Para pemasar hanya mementingkan adanya label halal yang menempel pada kemasan produk. Penelitian mendatang perlu dilakukan kajian mengenai tata letak yang tepat dalam menempatkan logo halal dari MUI, termasuk juga besar kecilnya ukuran logo tersebut.

Hasil penelitian ini menguji dua model alternative, dimana model yang pertama (M1) kejelasan label halal merupakan variable independent, dan model yang ke dua variable kejelasan label halal merupakan variable moderasi. Sebagai kesimpulan model pertama (M1) lebih tepat dibandingkan model ke dua (M2), sehingga hal ini mengkonfirmasi bahwa model yang digunakan oleh peneliti sebelumnya adalah sudah benar. Namun demikian, untuk perlu juga diteliti model moderasi / M2 untuk jenis produk lainnya, seperti makanan dan minuman atau jasa layanan. Sehingga dapat dipastikan apakah model alternatif, model moderasi, M1, dapat berlaku untuk jenis produk tertentu.

Penelitian lainnya juga dapat dilakukan, dimana ada kemungkinan bahwa hablumminallah dapat mendorong hablumminannah. Dimana seorang yang berperilaku baik terhadap Allah juga tergerak hatinya untuk berperilaku baik terhadap sesame manusia. Dengan pemikiran yang demikian, perlu dilakukan penelitian yang khusus meneliti apakah kedua konsep tersebut merupakan variable independen, atau ada salah satunya yang menjadi variable mediasi terhadap minat beli. 
Islamiconomic: Jurnal Ekonomi Islam Vol.10 No.2 Juli - Desember 2019

Sebagai kesimpulan umum, kejelasan label halal dan perilaku beragama dalam penelitian ini terbukti dapat mendorong minat beli. Selanjutnya kejelasan label halal bukan sebagai variable moderasi, tetapi merupakan variable independen bersamasama dengan perilaku beragama. Namun demikian hal tersebut berlaku untuk jenis produk pembersih wajah, khususnya Fresh Care, dan untuk jenis produk lainnya perlu diadakan penelitian lanjutan.

\section{PUSTAKA ACUAN}

Aidi Matriani, Muhammad. Pemikiran Ibnu Taimiyah Tentang Mekanisme Pasar Dalam Ekonomi Islam. Mahasiswa fakultas Agama Islam (Syariah) Universitas Muhammadiyah Surakarta. 2008.

Aisyah, Muniaty. Consumer Deman on Halal Cosmetics and Personal Care Products in Indonesia. Jurnal Ekonomi Syariah, vol 9, no 1. 2014.

Ajzen, I. and Fishbein, M. The prediction of behavior from attitudinal and normative variables, Journal of Experimental Social Psychology, Vol. 6, pp. 466-88. 1985, Apriyanto, Anton dan Nurbowo. Panduan Belanja dan Konsumsi Halal. Jakarta: Penerbit Khairul Bayaan. 2003.

Burhanuddin. Pemikiran Hukum Perlindungan Konsumen dan Sertifikat Halal. Malang: UIN-MALIKI PRESS. 2011.

Bonyadi, Ali. Naeini, Parisa Roshanpanah Azali, and Khosro Sepehr Tamaddoni. Impact of Brand Equity on Purchase Intention and Development, Brand Preference and Customer Willingness to Pay Higher Prices. Management and Administrative Sciences Review. Volume 4, Issue 3, Pages: 616-626, May, 2015 Ghozali, Imam. Aplikasi Analisis Multivariate Dengan Program SPSS. Semarang: Badan Penerbit Universitas Dipenogoro. 2011.

Hidayat, Bagja. Bisnis Global Petinggi Majelis, Tempo, Majalah Berita Mingguan Edisi 4252, 24 Februari-2 Maret 2014, Jakarta: hal. 42-44, 46. 2014.

Kotler, Philip dan Amstrong. Princeples Of Marketing. Edisi 13. England: Pearson LPPOM MUI Jawa Tengah, Daftar Produk-produk Bersertifikat Halal. 2013.

Listyoningrum, Anggit. Analisis Minat Beli Konsumen Muslim Terhadap Produk yang Tidak Diperpanjang Sertifikat Halalnya. Journal Ekonomi \& Keuangan Islam. Volume 2. No1. Halaman 40-51. 2012. 
Wahyu Dwi Aprianto, dkk.: Pengaruh Kejelasan Labelisasi...

Magill, F. N. (Editor). Survey of Social Science: Psychology Series (Vols. 16). Pesadena, California: Salem Press. 1993.

Mansoer, Masri. Perilaku Keberagamaan Remaja Kasus Pada Siswa SLTA Di Kota Jakarta Selatan, Kabupaten Sukabumi dan Kabupaten Lebak, Disertasi Pascasarjana, Institut Pertanian Bogor. 2008.

Mc Cracken. Grant. Cultural and Consumption: A Theoretical Account of the Structure and Movement of the Cultural Meaning of Consumer Goods. Journal of Consumer Research. Vol 13, June, page 71 - 84. 1986.

Rangkuti, F. Strategi Promosi yang Kreatif, Jakarta: PT.Gramedia Pustaka Utama. 2009.

Robertson, Rolan. ed. Sociology of Religion (translation. Ahmad Fedyani Saifuddin), Jakarta: Grasindo Persada. 1998.

Sekaran, Uma. Metode Penelitian, Penelitian Untuk Bisnis. Salemba Empat. 2011.

Schiffman, LG. dan Kanuk, L,L. Perilaku Konsumen. Edisi Ketujuh. Prentice Hall International. 2004.

Sirgy, M Joseph. Jeffrey E Danes. Self Image / Product - Image Congruence Model: Testing Selected Models. Advances in Consumer Research, Vol 9. Page 556561. 1982.

Utami, dan Wahyu Budi. Pengaruh Label Halal Terhadap Keputusan Membelian (Survei Pada Pembeli Produk Kosmetik Wardah di Outlet Wardah Griya Muslim an-Nisa Yogyakarta). Skripsi. Yogyakarta: Fakultas Ilmu Sosial dan Humaniora UIN Sunan Kalijaga. 2013.

Wibowo, Nugraha Agung. 2010. “Pengertian Hablum Minallah Dan Hablum Minannas”, 3 Februari 2010 